\title{
Oil and ethnic inequality in Nigeria
}

\author{
James Fenske $^{1}$ • Igor Zurimendi ${ }^{2}$
}

(C) The Author(s) 2017. This article is an open access publication

\begin{abstract}
Although it is known that ethnic biases exist in Africa, less is known about how these respond to natural resource prices. Many ethnically fragmented African countries depend on a small number commodities for their export base. Oil prices experienced in early life predict differential adult outcomes across Nigerian ethnic groups. Our differencein-difference approach compares members of southern ethnicities to other Nigerians from the same birth cohort. This North-South distinction mirrors several economic, political, and religious cleavages in the country. Greater prices in a southern individual's birth year predict several relative outcomes, including reduced fertility, delayed marriage, higher probabilities of working and having a skilled occupation, greater schooling, lower height, and greater BMI. These microeconomic impacts are explained by macroeconomic responses to oil prices; relatively, urban incomes increase, food production declines, and maternal labor intensifies in the South.
\end{abstract}

Keywords Commodity prices $\cdot$ Early life $\cdot$ Ethnicity $\cdot$ Nigeria

JEL Classification $\mathrm{I} 12 \cdot \mathrm{I} 15 \cdot \mathrm{O} 12$

We are grateful to Achyuta Adhvaryu, Miriam Omolo, Anja Tolonen, Kevin O'Rourke, and seminar participants at the Universitat Autònoma de Barcelona, the University of Edinburgh, the University of Maryland, the University of Oxford, and the University of Oslo for their comments.

Electronic supplementary material The online version of this article (doi:10.1007/s 10887-017-9149-8) contains supplementary material, which is available to authorized users.

James Fenske

j.fenske@warwick.ac.uk

1 University of Warwick, Coventry, UK

2 London, UK 


\section{Introduction}

In this paper, we ask whether members of African ethnic groups benefit differentially from positive commodity price shocks in resource producing countries. The division of increased returns to commodity production is central to whether or not natural resources contribute to development and growth (Sachs and Warner 2001; Mehlum et al. 2006). Further, ethnic fragmentation is an important component of Africa's growth tragedy (Easterly and Levine 1997; Posner 2004). We focus on Nigeria. Nigeria is dependent on oil; oil rents accounted for 26.8\% of GDP in 2012 (World Bank 2012) and oil provided $70 \%$ of government revenues in 2011 (NRGI 2013). Nigeria is well known for failing to convert its resource windfall into development. From 1960 to 2000, more than \$350 billion in oil revenue in 1995 dollars was collected by the Nigerian government while, depending on the estimate, real income per capita either fell or made only modest gains (Marwah 2014). ${ }^{1}$ During the oil boom of the 1970s, government spending and access to international capital increased, but annual production of Nigeria's major cash crops declined (Pinto 1987).

By testing whether members of certain ethnic groups benefit differentially from positive oil shocks, we assess the distributional impacts of oil price changes across regions and across ethnicities. This task is made difficult by the absence of nationally representative sub-national data on individuals' living standards over long periods of time. For example, the Nigeria Living Standards Measurement Study covers only three waves, the first in 2010. The first national survey from which a distribution of living standards can be computed took place in 1992 (Bevan et al. 1999, p. 100). Tracing the relative impacts of changing oil prices is not as simple as measuring the distribution of government spending over space, since many macroeconomic responses to oil are not driven by government spending. We focus, then, on final outcomes for individuals. Our approach is to test whether real oil price shocks experienced in early life affect human capital outcomes of members of Nigeria's ethnic groups. This allows us to recover the ultimate distribution of the relative impacts of changes in oil prices.

We use individual data on women from the nationally representative 2008 Nigeria Demographic and Health Survey (DHS). We employ a difference-in-difference approach that exploits variation over time within ethnic groups and that compares members of Southern ethnic groups to other Nigerians born in the same year, allowing for ethnicity-specific time trends. Though our baseline North-South distinction is coarse, it features prominently in the secondary literature (e.g. Archibong 2016; Dev et al. 2016; Falola and Heaton 2008). The bulk of Nigerian oil is produced in the Niger Delta region of the south. Levels of education have been higher in the south since at least 1960, and members of southern ethnic groups are over-represented in the professions and the civil service. Control of the executive between independence and the return to democracy in 1999 was predominantly held by Northerners. While the south received more colonial missions and is predominantly Christian, the North is predominantly Muslim. The North-South distinction is also reflected in the data. We disaggregate our effects into finer ethnic categories, and show that outcomes for multiple southern groups and multiple northern groups move together in response to oil prices. Delta ethnicities, in particular, have outcomes whose responses to oil prices resemble those of other southern groups.

Although oil is important to Nigeria, the country is a small producer and part of the "competitive fringe" that does not coordinate its production quantities with OPEC (Griffin

1 A large literature is cited below that seeks to explain Nigeria's growth failure. One neglected factor is Malthusian pressure (e.g. Galor and Mountford 2008). Nigeria's total fertility rate rose during the oil boom. 
1985). World oil prices, then, can be taken as exogenous from the Nigerian perspective. ${ }^{2}$ These correlate strongly with the total value of Nigerian oil production, without being potentially contaminated by an endogenous production quantity response.

Our main finding is that relative economic outcomes for Southern groups respond positively to oil prices, but that relative health outcomes respond negatively. Positive oil price shocks increase years of education, make a woman more likely to have a skilled occupation and to be in work, reduce fertility, and raise age at first marriage compared to a woman from a Northern ethnic group born in the same year. However, positive oil price shocks reduce relative height and increase relative BMI. The effects we find are economically meaningful. Across our outcome variables, a one standard deviation movement in early-life oil prices changes the outcome variables by roughly 0.05 to 0.10 standard deviations, magnitudes that are similar to other early life treatments in the literature.

Why are these findings significant for economic thought? Ethnic inequality reduces growth through civil conflict, limited public goods provision, lower social capital, and distrust of market economies (Alesina et al. 2016). Despite its importance, the origins of ethnic inequality are not well understood. Existing empirical work has focused on political variables such as control of the executive (Burgess et al. 2015; Franck and Rainer 2012). Alesina et al. (2016) show that inequality in geographic endowments predicts inequality across ethnic groups. And yet our results are both net of time-invariant factors such as geography and reveal relative Southern gains in a time of Northern political dominance. Our results demonstrate, then, that additional factors contribute to this important determinant of economic growth.

Our results can be understood as microeconomic responses to the macroeconomic changes prompted by oil prices. While there are several complicated mechanisms driving our results, we focus in this paper on a core set of changes that have been emphasized in the secondary literature, that are consistent with the empirical results that we find, and that we can evaluate empirically. In the appendix, we present several additional results that we use to evaluate a larger set of possible mechanisms. These changes are not as simple as local economic spillovers in the areas where oil is produced; we find little difference in responses between the oil-producing Delta region and the remainder of Southern Nigeria. The oil sector employs less than $1 \%$ of the Nigerian labor force (Fajana et al. 2005).

The existing literature has argued that oil revenues spurred a decline of agriculture, volume growth in the oil sector, and increasing urban employment in services and manufacturing (Bevan et al. 1999, p. 186). The secondary literature emphsizes that the decline of agriculture and growth of urban services and manufacturing employment was greater in the South, due to a variety of factors such as the labor-intensiveness of Southern agriculture and the high wages in oil and related urban sectors (Scherr 1989; Walker 2000; Khan 1994). The secondary literature also notes that the gap between the richer South and the poorer North grew during the oil boom (Bevan et al. 1999, p. 107). Manufacturing grew in the South where it had been traditionally concentrated, and rising managerial, professional, and public sector employment drew from the Southern ethnic groups that were already over-represented in these sectors (Mustapha 2006). We indeed show empirically that our results can be partly explained by the levels of education that predated the oil boom, and that oil prices accentuated baseline differences between the North and South.

Our results support a similar story. Southern households benefit economically relative to the North from positive oil price shocks, and use this advantage to invest in more, bettereducated (though not necessarily healthier) children. Adverse health effects result in part

2 The existing literature takes Nigeria to be a price taker: see Abidoye and Calí (2015), Chuku et al. (2011), Lukonga (1994), or Wlazlowski et al. (2011). The correlation of the log real oil price and Nigerian oil production over the period 1958-2004 is positive, with $\rho=0.5094$. 
because Southern households face a greater opportunity cost of time and reduce some earlylife investments in their children, particularly vaccinations. ${ }^{3}$ Additional explanations of the relative adverse health effects include urbanization and food prices. Using additional waves of the DHS data, we show that indeed Southern households have more assets and women are more likely to work when oil prices are higher. We show a strong negative correlation between Nigerian per capita food production and oil prices. We also find that men in southern Nigeria are relatively less likely to work in agriculture in years of high oil prices.

\subsection{Related literature}

We contribute to the literatures on ethnic inequality, early life shocks and investments, and the effects of commodity price shocks in general and natural resource windfalls in particular.

The importance of ethnic divisions for outcomes such as government quality, conflict and public goods provision is not limited to Africa (Baldwin and Huber 2010; Esteban et al. 2012). Large intra-country differences in economic development exist across ethnic groups in much of Africa (Michalopoulos and Papaioannou 2013). The importance of Africa's ethnic divisions for outcomes such as the distribution of political power (Francois et al. 2015), the provision of public goods (Glennerster et al. 2013; Franck and Rainer 2012), and the incidence of conflict (Desmet et al. 2012; Michalopoulos and Papaioannou 2016) has been the subject of considerable quantitative research. Most of the literature has focused on the consequences of ethnic politics on macroeconomic outcomes.

Our study adds to this literature by considering whether positive commodity price shocks increase the relative standing of specific ethnicities in a way that improves outcomes for their members. We thus add evidence on the time-varying sources of ethnic inequality, and on the importance of shocks other than the distribution of political power that can alter the relative fortunes of a country's ethnic groups. Our results are consistent with the pattern highlighted by Chua (2004), in which external economic shocks can amplify existing ethnic differences within countries.

Existing research has looked at the impact of many different early life shocks, including disease burdens, weather, and government assistance programs (Almond 2006; Maccini and Yang 2009; Hoyne et al. 2016). In particular, this literature has focused on the "fetal origins" of long-run health (Almond and Currie 2011). We assess a broad range of adult outcomes, including education and marriage behavior. Our contribution to this literature is two-fold. First, we add to the empirical evidence on whether parental investments mitigate or reinforce early life shocks and, if so, how effectively. Recent work has suggested that parental investments are mostly reinforcing (Adhvaryu and Nyshadham 2016; Almond and Mazumder 2013) and that the investments made early in life are particularly productive (Cunha et al. 2010; Bharadwaj et al. 2013). We do not find strong evidence of reinforcing investments, as Southern mothers invest less in vaccination years of higher oil prices. Second, though the literature on early life circumstance is extensive, little of it has focused on the impact of strictly economic shocks such as commodity prices, notable exceptions being Adhvaryu et al. (2014a) and Cogneau and Jedwab (2012). This is despite the particular vulnerability of poor countries to movements in commodity prices (Deaton 1999).

The third body of research our paper is related to concerns the political economy and human capital effects of commodity price shocks. Existing work has considered the importance of these shocks for outcomes such as conflict (Brückner and Ciccone 2010), health spending (Acemoglu et al. 2013), government fiscal positions (Arezki and Brückner 2012), household

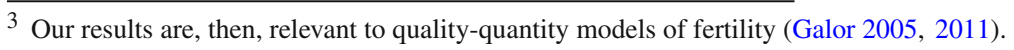


enterprize (Adhvaryu et al. 2014b), and child outcomes such as survival, schooling and labor (Kruger 2007; Miller and Urdinola 2010). Oil is a capital-intensive "point source" resource, and so price increases might be expected to have adverse effects on conflict and health outcomes. Existing studies have found that oil rents may reduce democracy (Tsui 2011), increase corruption (Arezki and Brückner 2011), and reduce the status of women (Ross 2008). We add to this literature by considering the long-run effects of these shocks, heterogeneity in responses to these shocks at the sub-national level, and the degree to which short-term responses help explain long-run outcomes.

The remainder of the paper is organized as follows. Section 2 provides background on oil production and the political economy of economic growth in Nigeria. Section 2 also outlines our conceptual framework: our understanding of the macroeconomic responses to oil prices that explain our microeconomic outcomes. Section 3 explains our identification strategy and outlines our sources of data. Section 4 presents results. Section 5 tests between potential mechanisms. Section 6 concludes.

\section{Background and conceptual framework}

\subsection{Background}

\subsubsection{Oil in Nigeria}

Oil production in Nigeria began in December 1957. From 1970, crude oil has been Nigeria's main export, accounting for over $90 \%$ of Nigeria's exports over the past four decades (Udosen et al. 2010). The oil boom of the 1970s was one of rapid capital accumulation, declining total factor productivity, and shrinking capacity utilization. Since oil has become dominant, Nigerian growth has been exceptionally volatile (Sala-i-Martin and Subramanian 2013). As a consequence, the size of government has also been volatile (Ross 2003). Though there is no evidence that the relative price of tradable goods to non-tradable goods followed the classic "Dutch Disease" pattern, it is clear that the agricultural sector declined in favor of services, especially government services (Sala-i-Martin and Subramanian 2013).

Oil revenue accrues to the central government through its ownership of the Nigerian National Petroleum Corporation, which operates the contracts for oil production between the Nigerian government and the private oil companies that are in charge of production. Taxes are collected on the profits from petroleum production, and government revenue is sensitive to the price of oil.

Since the beginning of oil production, there has been considerable fluctuation in the fraction of oil revenues that remain in the producing state. Between 1946 and 2003, the rules for revenue allocation were changed eighteen times (Ross 2003). Until 1975, states kept up to $45 \%$ of oil revenues, falling to $20 \%$ from 1975 to 1979 and then to less than 5\% until 1999 . Under the 1999 constitution, at least $13 \%$ of revenue must be transferred to oil-producing states (Fig. 1), which has resulted in an upward jump in the fraction of oil revenues going to oil-producing regions (Nigeria 2006). We do not use these rule changes in our empirical work; none of the women in our sample were born after 1999, it is not clear these rules reflect actual spending, and we do not propose that government spending is necessarily the principal mechanism behind our main results.

Government revenues during the high oil prices of the 1970s are largely understood to have been misspent. Spending on the military and education maintained a large non-productive 


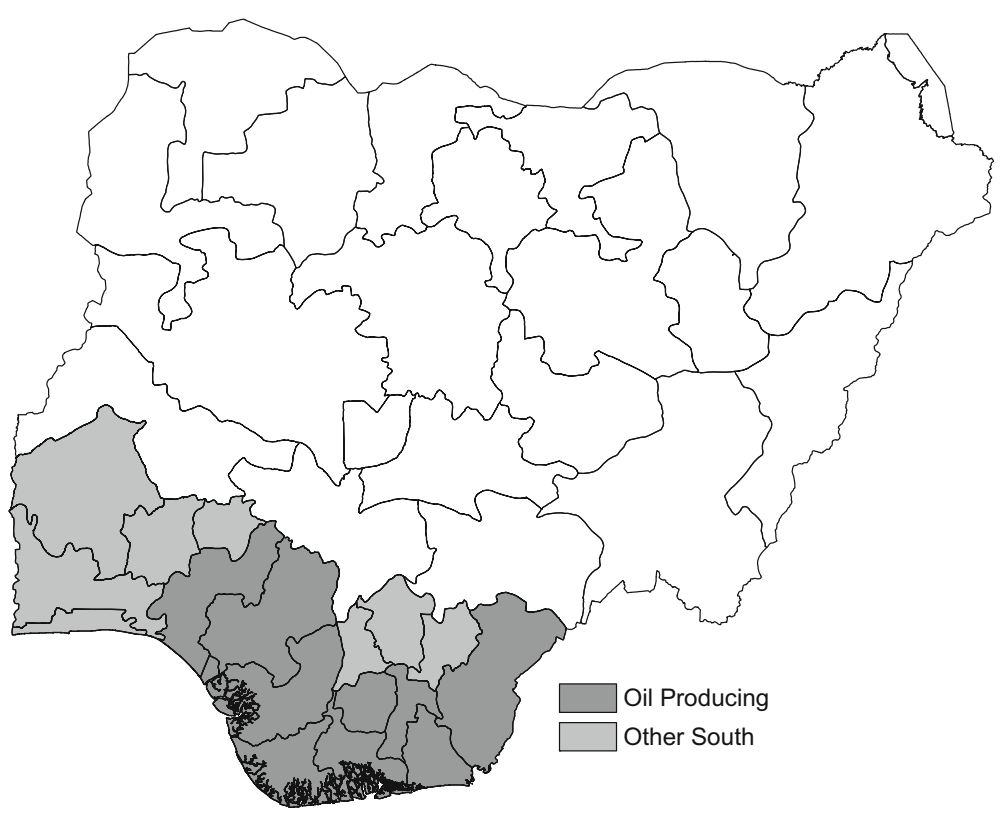

Fig. 1 The South and the oil producing states

population (Freund 1978). Although some of the revenues were invested in projects such as school building, some two thirds of officially recorded "investment" was not in fact investment; much of this spending instead went to "ghost construction" of projects that were paid for but never completed (Marwah 2014).

In section A in the appendix we provide background on ethnic bias in Nigeria.

\subsection{Conceptual framework}

We argue that the Nigerian oil boom led to greater structural transformation in Southern Nigeria than in Northern Nigeria, and that this explains the changing regional differences we see across birth cohorts. Our main results are consistent with the scattered evidence from the secondary literature that the North-South income divide widened during the oil boom (Bevan et al. 1999, p. 107). This was driven by the relative expansion of manufacturing, services, and commerce in the South, and occurred despite the relative decline of Southern agriculture. Although the North dominated politics, general equilibrium effects outweighed direct transfers, which were themselves mitigated by political compromise (Bevan et al. 1999, p. 187).

Manufacturing defied the standard "Dutch Disease" pattern and expanded during the oil boom. Several reasons have been proposed for this, including the non-market allocation of resources (Bevan et al. 1999, p. 51,113), government support for specific industries (Bienen 1988, p. 243), protectionism (Adenikinju and Alaba 1999, p. 255), an overvalued exchange rate that cheapened the import of raw materials and intermediate goods (Struthers 1990), and the downstream location of some manufacturing activities from oil (Struthers 1990). Manufacturing gains were naturally most pronounced in the South, where the sector had long been concentrated (Mustapha 2006, p. 9). 
New urban wage earners benefitted from the oil boom. Until the 1980s, living standards were clearly higher in urban than rural areas, particularly for wage earners (Bevan et al. 1999, p. 66, 100). While this was partly driven by manufacturing and services, this urban expansion was also driven by employment in the government sector. Further, civil service wages increased dramatically during the oil boom (Bienen 1988, p. 241). This disproportionately benefitted members of Southern ethnic groups, who have been over-represented in both federal and lower-level public employment through the post-colonial period (Mustapha 2006, p. 25,29).

The Northern elite was comparatively poorly placed to benefit from the expansion of commercial activity (Bevan et al. 1999, p. 66). Even without government involvement, expansion of the private sector would be expected to have disproportionate effects on the South. According to Mustapha (2006, p. 31):

Ethnic inequalities are pervasive in Nigeria, affecting not just the public sector, but also the private sector. Invariably, the senior management and professional cadre of industries and businesses also reflect the patterns of inequalities in educational and professional achievements, with the southwest and southeast having the largest numbers of private sector professionals.

Taking rising incomes in a growing Southern urban sector as given, the microeconomic outcomes we observe can be understood. A large literature exists emphasizing that conditions in early life predict later life outcomes, such as socio-economic status, education, and income (Almond 2006; Almond and Currie 2011). Though many of these studies focus on health, this is unlikely to explain our results concerning education, fertility, marriage, and work. Relative height and BMI outcomes for members of southern ethnic groups are worse for those born in times of high oil prices; the literature generally takes these as measures of adverse health conditions in early life (e.g. Hoyne et al. 2016). For the same reason, parental investments that reinforce health endowments (e.g. Almond and Mazumder 2013) are unlikely mechanisms.

Rather, the outcomes we consider are themselves products of the incomes, prices, and time constraints faced by an individual's parents (Blau 1999), all of which are affected by the macroeconomic changes described above. Increases in education, work, skilled work, and age at first marriage, as well as declines in fertility are all consistent with a southern individual having been raised in an urban environment where public services are more easily available and parental incomes are higher. Parental income may improve these outcomes by helping parents more easily provide education, ability, noncognitive skills, or labor market experience to their children (Blanden et al. 2007). Greater income-particularly if it is perceived as permanent — can reduce parents' stress and depression, while improving their health, social standing, and ability to afford books, child care, schooling, better housing, and residence in a better neighbourhood (Dahl and Lochner 2012; Hoyne et al. 2016; Maurin 2002; Milligan and Stabile 2011). Further, oil prices and greater incomes may both have changed the input prices faced by Nigerian parents (Currie and Almond 2011).

The availability of education, in particular, will have been improved due to the 1976-1981 Universal Primary Education program that was funded by the oil boom, though our results, contra Osili and Long (2008), suggest that it was members of southern ethnic groups who were the principal beneficiaries. The relative increase in education itself partially explains the relative changes found in skilled work, fertility, and age at first marriage. Several studies have shown that women who receive more education are more likely to work in better jobs, marry later, and have fewer children (e.g. Duflo et al. 2015; Isen and Stevenson 2010). While we focus on incomes in early life, performance in the early years of education facilitates ultimate 
educational attainment. Education is not, however, a sufficient statistic, in that controlling for years of schooling does not render any of the other results insignificant.

It is not the case, however, that all parental investments should be expected to rise in response to the macroeconomic changes outlined above. Other studies have shown that maternal labor force participation, for example, may reduce time-intensive investments in children or adversely affect their health (Dehejia and Lleras-Muney 2004; Miller and Urdinola 2010), though theoretical predictions are ambiguous (Currie and Almond 2011). In addition, relative health effects in the South may be worsened by the sanitary environment in urban areas, reduced availability of nutritious food as agriculture declines, and in-migration from other regions that strains local infrastructure. ${ }^{4}$

\section{Data and identification strategy}

\subsection{Data}

\subsubsection{Outcomes}

The main source of data for this study is the Nigerian DHS, carried out by the Nigerian National Population Commission. For 2008, the DHS interviewed a nationally representative sample of 33,385 women aged 15-49. These data were collected by a stratified two-stage cluster design that was intended to provide a representative sample at both the national and state levels. Though there is no claim that the data are further representative at the ethnic group level, there is no indication that the sampling procedure is likely to have provided a systematically unrepresentative sample of any particular ethnic group.

Our data cover women born between 1958 and 1993. Nigeria was an oil-producing country for all the years of birth covered by the DHS data. The survey questionnaire for women asks about a wide variety of health and fertility indicators that we consider. We report summary statistics in Table B.1 in the appendix. A little over $40 \%$ of our sample consists of women from Southern ethnic groups.

\subsubsection{Oil prices}

The oil price used is the West Texas Intermediate price in 1984 US dollars taken from Federal Reserve Economic Data (FRED). In Fig. 2, we plot the log of the real oil price and Nigerian oil production in millions of barrels. The graph shows considerable fluctuation in oil prices from the first oil crisis in 1973, with both large increases and declines being observed within the period we analyze. This allays concerns that we are identifying the consequences of one large temporary shock to the oil price or that our identification is based on a smooth trend. Oil production in Nigeria starts from a low base in our sample period, but increases before the oil crisis and then fluctuates thereafter. For the majority of the sample period there is considerable oil production in Nigeria, but our results are robust to excluding the period before 1970, when the dominance of oil relative to all other exports begins.

\footnotetext{
4 Our work is, then, linked to a broader literature that relates economic development, female labor force participation, education, and endogenous fertility (Galor and Weil 1996, 2000; Vogl 2015).
} 


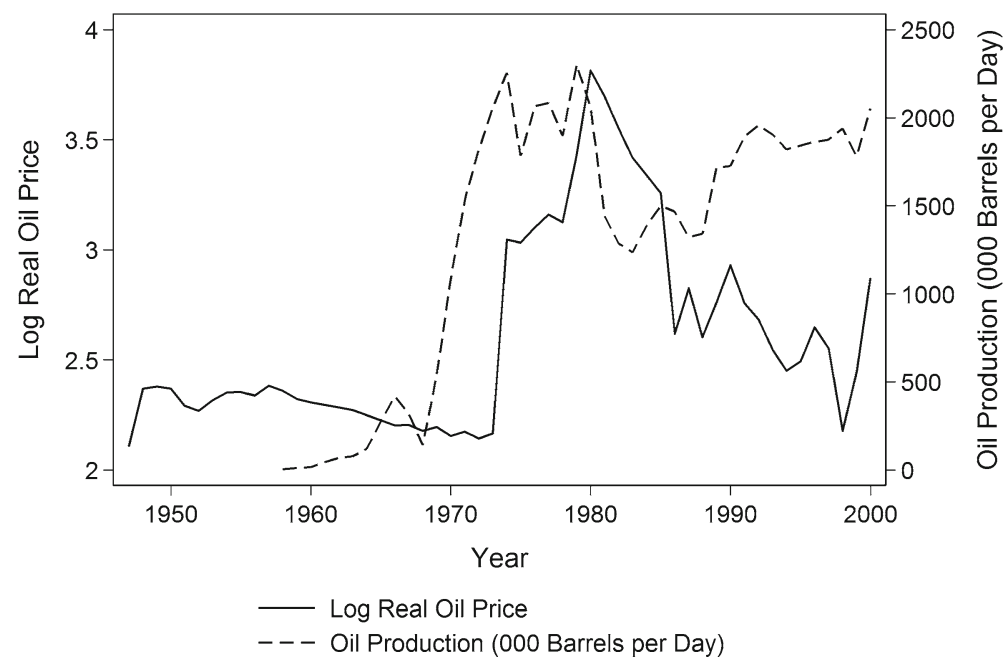

Fig. 2 The real oil price and Nigerian oil production

\subsubsection{Mechanisms}

We collect data on agriculture from the Food and Agriculture Organization's FAOSTAT website. ${ }^{5}$ This source reports the real value of food production for Nigeria as a whole in 2004-2006 international dollars. We are not aware of panel data on Nigerian food production at a sub-national level that overlaps with the period of the oil boom, or that covers a period of more than three years. We do discuss below whether the cultivation of crops specific to Northern or Southern Nigeria responds to oil prices.

We collect data on investments from the children's recode section of the DHS. For each standard DHS survey, women are asked multiple questions about children born in the past five years, such as the vaccinations they received, how long they were breastfed, and the circumstances of their births. Three waves of the Nigerian DHS include ethnicity data that allow us to classify these recently-born children as "Northern" or "Southern": 1999, 2003 and 2008. Similarly, the individual recode portions of the DHS from these three waves also inform us about the status of women of child-bearing age. In particular, we consider an indicator for having an earth floor, an indicator for having electricity, the weight of the respondent, an indicator for whether she is currently working, and an indicator for whether her partner works in agriculture.

\subsection{Identification strategy}

Our identification strategy attempts to isolate the effects of oil price changes on members of Southern ethnic groups relative to members of Northern groups through a difference-indifference approach. Changes in the oil price can be safely assumed to be exogenous, as Nigeria accounts for less than $4 \%$ of world oil production. ${ }^{6}$ Our regression equation is as follows:

\footnotetext{
5 http://faostat3.fao.org/.

6 See http://www.eia.gov/cfapps/ipdbproject/iedindex3.cfm?tid=5\&pid=53\&aid=1.
} 


$$
\begin{aligned}
\text { Outcome }_{i g t}= & \beta \ln \left(\text { RealOilPrice }_{t}\right)_{M A(3)} \times \text { SouthEthnicity }_{g} \\
& +x_{i g t}^{\prime} \gamma+\phi_{t}+\eta_{g}+\eta_{g} \times t+e_{i g t} .
\end{aligned}
$$

Here, Outcome $e_{\text {igt }}$ is the outcome for individual $i$ of ethnic group $g$ born in year $t$. The outcomes we consider are height, BMI, number of years of education, a dummy for working, age at first marriage, age at first birth, and number of children. The three year moving average of the logarithm of the West Texas Intermediate oil price, deflated by the US consumer price index (CPI), is $\ln \left(\text { RealOilPrice }_{t}\right)_{M A(3)} .^{7}$ SouthEthnicity $_{g}$ is a dummy variable that takes a value of one if the individual is part of an ethnic group for which over half the sampled population lives in the South of Nigeria. ${ }^{8}$ Since state of birth is not registered in our data, our use of ethnicity is a proxy for region of birth and is not susceptible to migration in response to oil prices. A positive coefficient on this variable indicates that the relative outcome responds positively to positive oil price shocks. Unless otherwise indicated, it is this composite variable $\ln \left(\text { RealOilPrice }_{t}\right)_{M A(3)} \times$ SouthEthnicity $_{g}$ that we refer to as the oil price "shock" in our tables and discussion.

$x_{i t}$ is a vector of controls that includes a constant. In our base specification, our controls include dummy variables for urban residence, female household head, region of residence, religion and survey month. These controls are chosen because they are plausibly exogenous, though our results are not sensitive to whether we include them. ${ }^{9}$ The region of residence fixed effects, similarly, ensure our results are driven not simply by living in the South, but being from a Southern ethnicity. $\phi_{t}$ and $\eta_{g}$ are fixed effects for year of birth and ethnic group, respectively. Our baseline specification also includes an ethnicity-specific time trend $\eta_{g} \times t$, which allows us to demonstrate that our results are not driven by regional trends correlated with oil prices. Standard errors are clustered at the ethnicity level.

Although we focus on the broad North-South distinction, it is feasible to consider a more disaggregate set of ethnic responses. The DHS data records more than 200 ethnic groups. We can estimate a separate effect for each group from the regression:

$$
\begin{aligned}
\text { Outcome }_{\text {igt }}= & \sum_{g=1}^{G} \beta_{g} \ln \left(\text { RealOilPrice }_{t}\right)_{M A(3)} \times\left(\text { Ethnicity }_{g}=g\right) \\
& +x_{i g t}^{\prime} \gamma+\phi_{t}+\eta_{g}+\eta_{g} \times t+e_{i g t} .
\end{aligned}
$$

We omit the Hausa as the modal category and present our results graphically on a map of Nigeria in Sect. 4, rather than presenting the more than 200 coefficients obtained.

\section{Results}

\subsection{Main results}

Table 1 summarizes our main results with the full set of controls for all outcomes. All our results are significant at the $1 \%$ level, and the standardized magnitudes of our results are

\footnotetext{
7 We use the moving average to alleviate measurement error, to capture the in utero period, and because of the salience of past income realizations with imperfect credit markets.

8 As a robustness check we consider excluding Lagos in determining our definition, as it is the recipient of immigration from across the country. Only a few small ethnic groups that each make up less than $1 \%$ of our sample are no longer defined as Southern according to this definition.

9 As a placebo exercise, we have made religion an outcome variable; the "shock" does not predict if a respondent is Catholic, Muslim, or an "other" Christian (not reported).
} 
Table 1 Main results

\begin{tabular}{llllllll}
\hline & $(1)$ & $(2)$ & $(3)$ & $(4)$ & $(5)$ & $(6)$ & $(7)$ \\
& Education & Skilled & Fertility & BMI & Height & Age at F.M. & Working \\
\hline Shock & $0.849 * * *$ & $0.0737 * * *$ & $-0.469 * * *$ & $0.415^{* * *}$ & $-0.573 * * *$ & $0.681 * * *$ & $0.106^{* * * *}$ \\
& $(0.145)$ & $(0.0109)$ & $(0.0940)$ & $(0.146)$ & $(0.166)$ & $(0.135)$ & $(0.0211)$ \\
Observations & 33,041 & 33,072 & 33,072 & 32,168 & 32,193 & 25,096 & 32,823 \\
Ethnic F.E. & Yes & Yes & Yes & Yes & Yes & Yes & Yes \\
Y.O.B. F.E & Yes & Yes & Yes & Yes & Yes & Yes & Yes \\
Controls & Yes & Yes & Yes & Yes & Yes & Yes & Yes \\
Ethnic Trends & Yes & Yes & Yes & Yes & Yes & Yes & Yes \\
\hline
\end{tabular}

*** Significant at $1 \%, * *$ Significant at $5 \%, *$ Significant at $10 \%$. Standard errors clustered by ethnicity in parentheses. All regressions are OLS. Controls are dummy variables for urban residence, female household head, region of residence, religion and survey month. All regressions include a constant. The "shock" is the interaction of the three year moving average of the log real oil price in an individual's year of birth with an indicator for Southern ethnicity, unless otherwise indicated

quite consistent. A one standard deviation increase in the year of birth oil price for women of Southern ethnic groups (around $0.5 \mathrm{log}$ points) results in a change relative to Northerners of between 0.05 to 0.10 standard deviations of the outcome variables. In absolute magnitudes, this change represents 0.43 more years of education, an increase of $3.7 \%$ in the probability of having a skilled occupation, 0.23 fewer children born, a BMI 0.21 points heavier, a fall in height of 0.29 centimeters, a 0.34 year increase in the age at first marriage, and an increase of $5.3 \%$ in the probability of working.

For comparison with other results in the literature, the relative decrease in years of education due to a one standard deviation fall in the oil price, 0.43 years, is larger in magnitude than that of being born in the influenza pandemic year of 1919 in the US ( 0.15 in Almond 2006). In a study of the effect of rainfall during year of birth on adult outcomes in Indonesia, Maccini and Yang (2009) find that a one standard deviation increase in rainfall increases grades completed by 0.33 and increases height by 0.86 centimeters. Our results are, then, of a plausible magnitude when compared to those found in previous studies in this literature.

In Fig. 3 we address the fact that variation in oil prices is annual and make our identifying variation explicit. Following Angrist and Pischke (2008), we collapse our data to the annual level. For each of our dependent variables of interest, we compute the mean difference between members of Northern and Southern ethnic groups by birth cohort. For each outcome, we regress this gap on the three year moving average of the real log oil price and a linear time trend. We show partial residual plots for each regression in Fig. 3. We report the estimated coefficient on the oil price measure as well as its standard error in each figure. Except in the case of BMI, these results confirm our baseline findings: members of Southern ethnicities born in years of high oil prices achieve greater levels of education, are more likely to have skilled occupations, have reduced fertility, lower heights, marry later, and are more likely to work compared to their Northern counterparts.

It is possible that our results are driven by one or two large ethnic groups that are disproportionately aided or harmed by oil prices. To determine whether this is the case, we disaggregate our definition of Southern ethnic group into the two largest groups, Igbo and Yoruba, Niger Delta ethnicities taken together, and other Southern ethnic groups taken together. We also divide the Northern ethnic groups into the two main groups, Hausa and Fulani, and other 

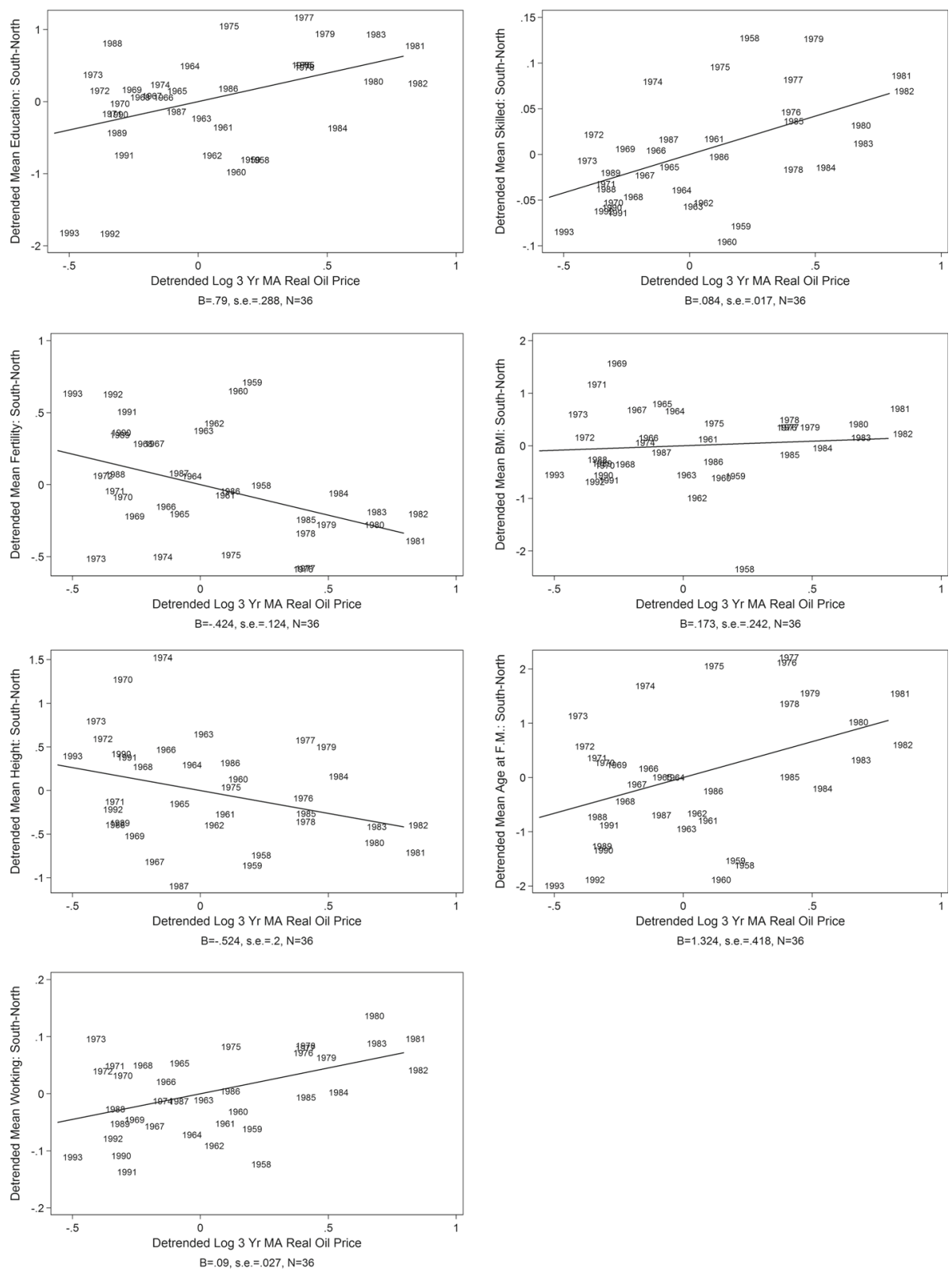

$B=1.324$, s.e. $=.418, N=36$

Fig. 3 Results collapsed to annual means. B and s.e. refer to the coefficient and standard error on the log real oil price in a regression of the detrended outcome listed on the y axis on the detrended three year moving average of the log real oil price, with robust standard errors. $\mathrm{N}$ is the sample size

Northern ethnic groups taken together. We interact all these new groupings with oil prices (with the exception of the Hausa who are our excluded category).

Results are reported in Table 2, and do not support the notion that our baseline results are driven by one ethnic group. For several outcomes, other Northern groups are indistinguishable 


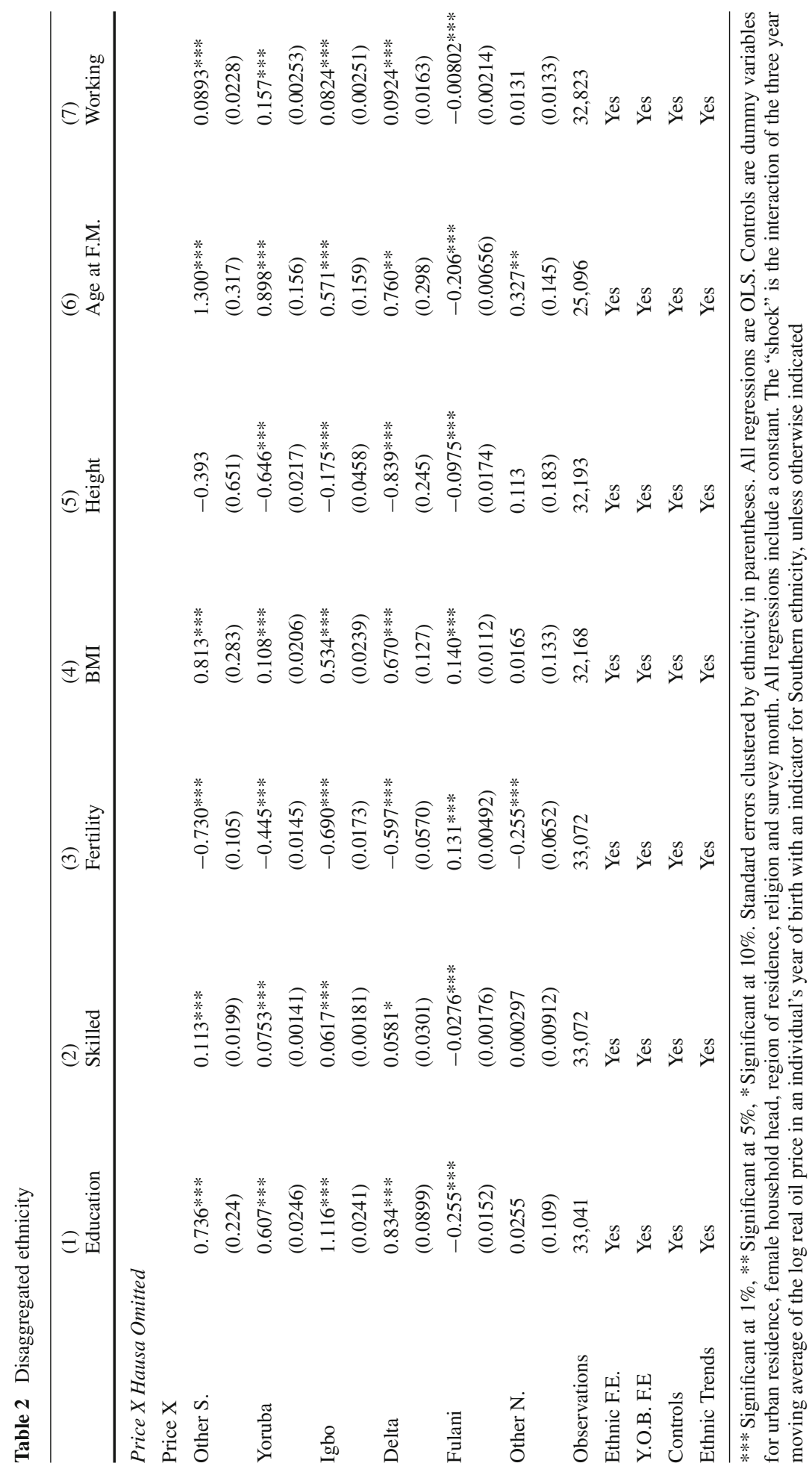


from the Hausa. The Fulani diverge even more sharply from the southern ethnicities than do the Hausa. Table 2 also demonstrates that results are not localized to the oil-producing Delta region, as Delta ethnicities show patterns broadly similar to those of the other southern ethnicities in the sample.

Within the Southern ethnic groups, there are significant differences in coefficient values for all outcomes, since estimates for the interaction of Igbo and Yoruba with oil prices are precise. However, the signs of the coefficients are always the same, and differences are rarely large in magnitude. This validates our baseline division of ethnic groups into northern and southern. Furthermore, none of our four divisions of Southern ethnic groups show consistently larger coefficients. The Yoruba, for instance, are the Southern ethnic group that benefits relatively least from oil prices in terms of education, but most in terms of probability of working.

We next implement the even more disaggregated specification given in (2). Rather than reporting each $\hat{\beta}_{g}$ estimate in a table, we plot a map of the estimated coefficients in Fig. 4. The units in this figure are Local Government Areas, and each is assigned the coefficient of the modal ethnic group in the DHS. The North-South gradient is clear in each figure. Although the intensity of response differs across southern groups, most southern LGAs have the same sign, while Northern LGAs (mostly in the Northeast, as the Hausa cluster in the Northwest and, as the omitted category, are depicted as zeroes) typically have the opposite sign. Though our baseline North-South distinction is coarse, this is an accurate reflection of the data. In Figure C.3, in the appendix, we present the same results mapped onto cells $0.5^{\circ}$ in latitude by $0.5^{\circ}$ in longitude.

We discuss the robustness of our results in appendix C. Our results for education, skilled occupation, fertility, age at first marriage and currently working are robust across a range of specifications. The results for BMI and fertility are more fragile.

\section{Mechanisms}

In this section we test between possible mechanisms through which early life increases in the oil price might affect outcomes for Southern ethnic groups relative to Northerners. Although the account given in the conceptual framework above draws largely on secondary sources, we are able to corroborate many of these mechanisms empirically. We show that Nigerian agriculture declined during the oil boom, and that there is some evidence that the oil boom accentuated pre-existing differences across these regions. In particular, the relative living standards of women of child-bearing age rose in the South during years of high oil prices, though our data here come from a more recent period. The response of parental investments to oil prices in this later period has been mixed.

This narrower and simpler focus of course leaves out several other regional changes in Nigeria that contribute further to our main results. We explore these in greater detail in the appendix, though we are often constrained to look at the responsiveness of possible mechanisms to oil prices in more recent periods for which data are available. In the appendix, we discuss the possible mediating and moderating roles roles for selective survival and fertility, violence, the provision of measurable public goods, democracy, and co-ethnicity with the president.

\subsection{Agriculture and industry}

The existing literature emphasizes the negative effect of oil production on food security in Nigeria. During the oil boom, the share of agriculture in GDP fell dramatically (Sala-i-Martin 


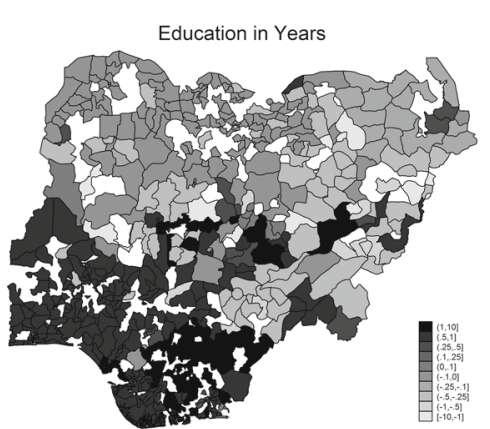

Total children ever born
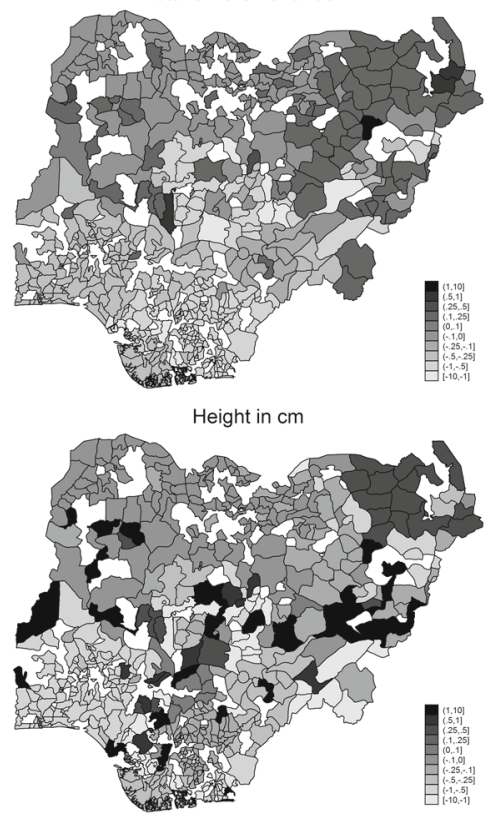

Currently working

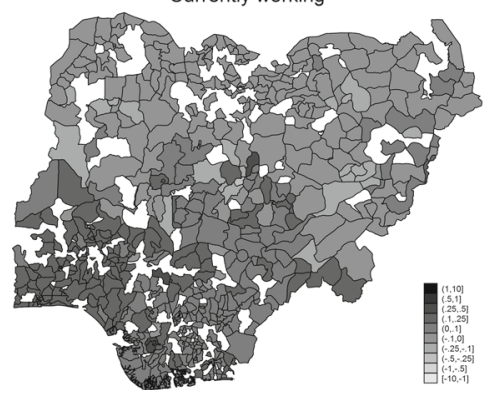

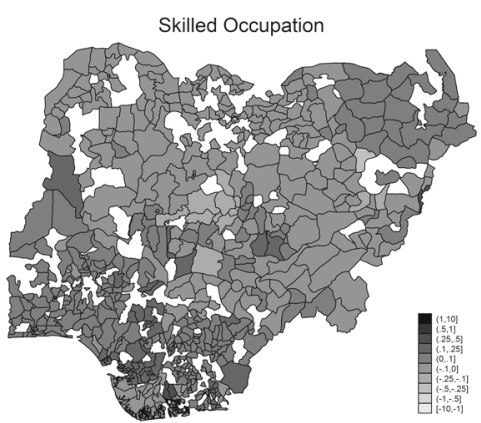

BMI

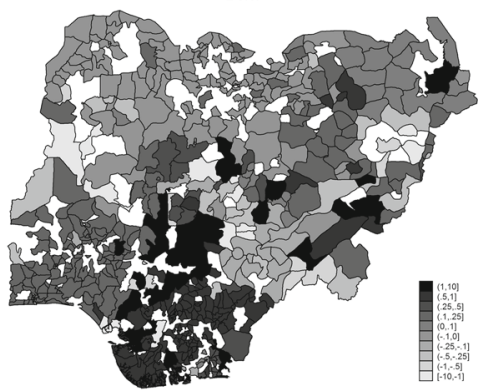

Age at first marriage

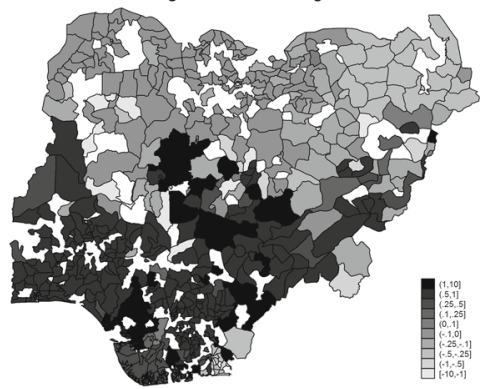

Fig. 4 Ethnic treatment effects over space. Each figure depicts the coefficient estimates from the regression: Outcome $_{i g t}=\sum_{g=1}^{G} \beta_{g} \ln \left(\text { RealOilPrice }_{t}\right)_{M A(3)} \times\left(\right.$ Ethnicity $\left._{g}=g\right)+x_{i g t}^{\prime} \gamma+\phi_{t}+\eta_{g}+\eta_{g} \times t+e_{i g t}$. In each Local Government Area, the coefficient $\hat{\beta}_{g}$ is shown for the modal ethnic group in the LGA. Variables are as defined in the text. Hausa is the omitted category and so is drawn as having a coefficient of zero. LGAs not containing respondents not drawn 
and Subramanian 2013). The cost of food rose relative to non-food goods by $170 \%$ between 1968 and 1979, to the particular benefit of larger farmers who were surplus producers (Collier 1983). Food production could not keep pace with urban demand (Scherr 1989). Indeed, Collier (1988) estimates that food production per capita declined during the oil boom as government spending diverted labor out of agriculture. Food imports rose with oil prices, propelled by real exchange rate appreciation and urbanization, while the agricultural sector was further harmed by erratic policies towards imports, pricing, and marketing (Pinto 1987; Freund 1978). Nominal exchange rates were kept constant on the belief that cheap imports would help preserve political stability by benefitting urban elites (Scherr 1989; Watts 2013).

We provide additional evidence for this mechanism using data from FAOSTAT. The FAO reports the Gross Production Value of food in Nigeria in constant 2004-2006 international dollars. We normalize this by population, also taken from the FAO. We show that Nigerian food production is negatively correlated with oil prices by estimating the following:

$$
\begin{aligned}
\log \left(\text { PerCapitaFoodProduction }_{t}\right)= & \alpha+\beta \ln \left(\text { RealOilPrice }_{t}\right)_{M A(3)} \\
& +\gamma \text { year }_{t}+\delta y e a r_{t}^{2}+\epsilon_{t} .
\end{aligned}
$$

Variables are as defined above. We use ordinary least squares with robust standard errors in our baseline. Results are similar with Newey-West standard errors, or if we use a linear rather than a quadratic time trend. We plot both time series in Figure D.4, in the appendix. The elasticity of per capita food production in response to oil prices is -0.227 with a standard error of 0.019. Though our data do not allow us to show whether this response was greater in the South, Scherr (1989) argues that the effect of oil was greater on Southern agriculture, due to the particular labor intensiveness of root and tree crop production, the higher wages in oil and related urban sectors in this region, and the collapse of export markets for Southern agricultural exports. Other writers have made similar claims. Walker (2000) argues that Southern export producers such as cocoa farmers were harmed by an overvalued exchange rate and rising labor costs as workers migrated towards better urban opportunities. Khan (1994, p. 187) suggests that the labor-intensiveness of southern agriculture made this latter pressure particularly acute.

\subsection{Baseline characteristics}

To what degree do our results reflect prior differences between Northern and Southern ethnic groups that made them likely to respond differently to the oil boom? In Table 3, we add additional controls to (1) that take the form $\ln \left(\text { RealOilPrice }_{t}\right)_{M A(3)} \times$ Baseline $_{g}$, and assess the degree to which these additional controls account for the coefficient we find on

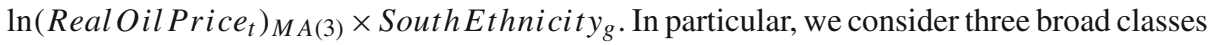

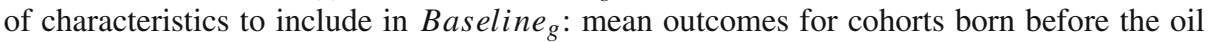
boom; pre-colonial state centralization, and; colonial missions.

For ease of notation, we report the coefficient on $\ln \left(\text { RealOilPrice }_{t}\right)_{M A(3)} \times$ Baseline $_{g}$ as Interaction in Table 3. In the first panel, our measure of Baseline $g$ is the mean years of education of members of ethnic group $g$ born in 1972 and earlier. Levels of education have long been higher in Southern Nigeria than in the North (Dev et al. 2016). While this does not explain away the majority of our results, it does make some of our coefficient estimates smaller. Notably, for education, fertility, and age at first marriage, the interaction is significant and has the same sign as coefficient reported in Table 1. For fertility and age at first marriage, the coefficient on the main shock variable becomes very small and insignificant, with all of the differential response of southern ethnic groups now loading on their pre- 


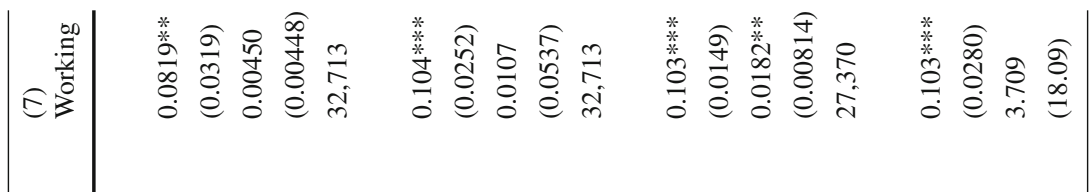

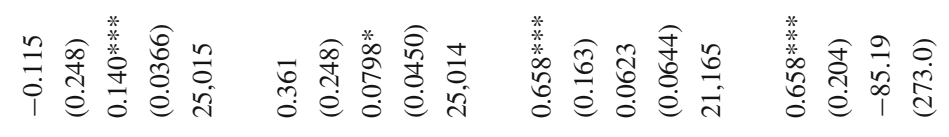

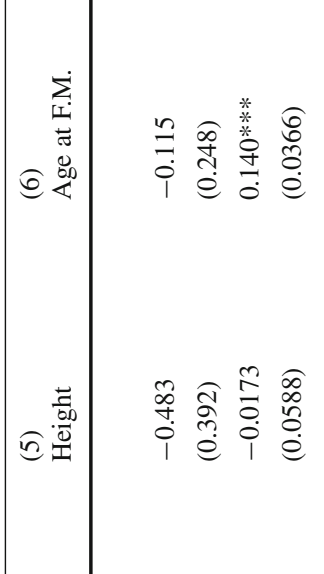

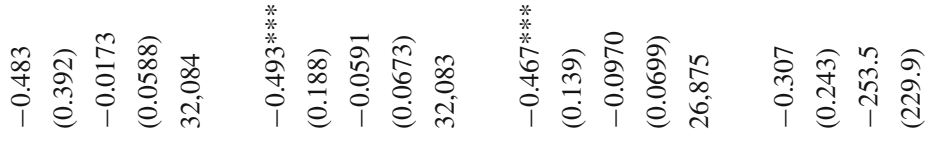

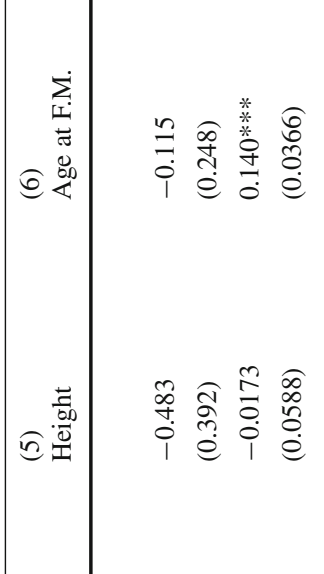

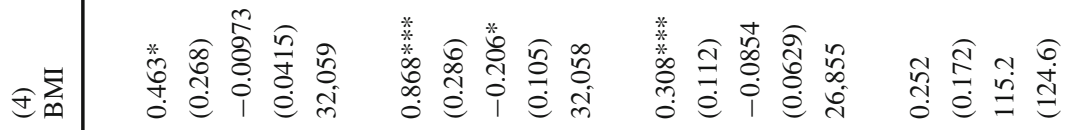

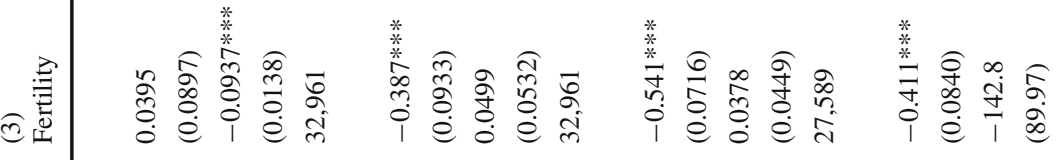

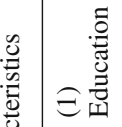

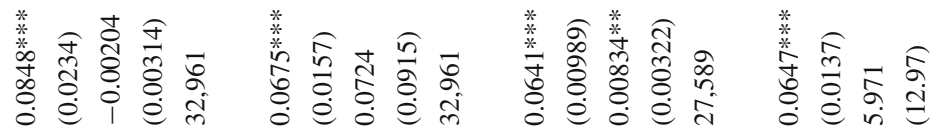

$$
\begin{aligned}
& \text { ลำ }
\end{aligned}
$$

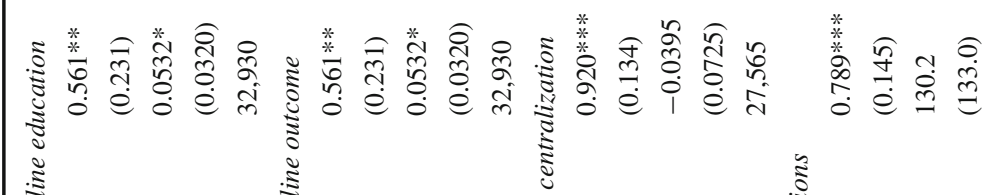

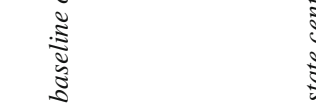

$$
\begin{aligned}
& \text { 产 }
\end{aligned}
$$

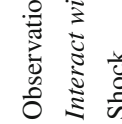

$$
\begin{aligned}
& \text { 高高毫 }
\end{aligned}
$$

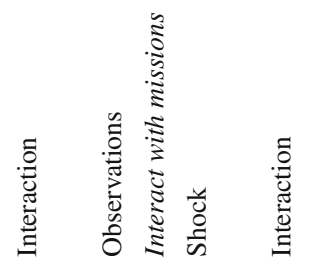$$
\text { 竞 }
$$ 


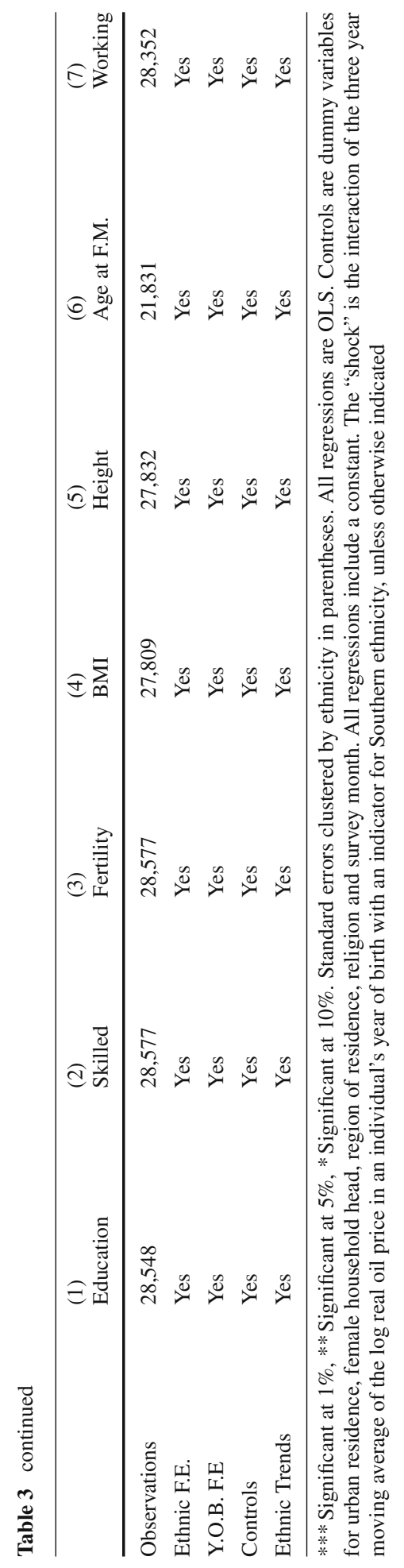


boom levels of education. These results suggest that the reason why southern women see their relative fertility decline and relative age at marriage rise is because southern women were initially more educated when the oil boom began. That is: high oil prices accentuated existing differences across regions. For height, the main result is now insignificant, though the interaction is also insignificant and the decline in the coefficient on the principal shock variable is minor. This is more consistent with collinearity than with education serving as the true mediating variable.

In the second panel of Table 3, we replace Baseline $g$ with the mean of the outcome variable for members of ethnic group $g$ born in 1972 and earlier. For education, this replicates the exercise in the first panel. For age at first marriage, there is some indication that the oil boom again led to differential responses across Northern and Southern ethnic groups because it strengthened their pre-existing differences. For skilled work, fertility, height and working, the interaction is insignificant, and so there is little evidence that the North-South differential response is explained by the different outcomes in these regions before the oil boom.

In the bottom two tables, we assess two other sources of pre-boom difference. First, following Michalopoulos and Papaioannou (2013) we consider precolonial state centralization. We merge the ethnic groups in the DHS to those for whom Murdock (1967) reports the levels of state centralization, between 0 and 3. Second, following Nunn (2014), we consider missions. We merge the map of missions in Roome (1925) to the map of ethnic groups in Murdock (1959), and further merge the ethnic groups in the DHS to these in order to compute the number of colonial missions per square kilometer. Pre-colonial state centralization does little to explain our main results. Missions too do little to diminish the coefficients on our baseline shock measure. The exceptions here are BMI and height. Though these are now insignificant, the interaction of the oil price with missions is also insignificant, suggesting that the difference with the the main result is driven by the loss of observations that could not be matched to an ethnic group in Murdock, as well as by collinearity, and not because missions explain the differential North-South response to oil prices.

\subsection{Investments}

In this section we consider the direct evidence for there being greater relative investments made in children born in years of higher oil prices, by looking at investments in child health and household circumstances. For child health, the DHS asks mothers a set of questions about their children aged five and under. Aggregating data for the three waves of the DHS for which information on ethnicity is available (1999, 2003 and 2008) we have information available for a series health interventions for children born from 1996 to 2008 . We use the specification in (1). Results are reported in Table 4.

There is mixed evidence that higher oil prices result in relatively fewer investments in child health by mothers of Southern ethnic groups. Higher oil prices result in more doses of the polio vaccine, but the incidence of other vaccinations falls. The anomalous result for polio may reflect both the degree to which polio vaccination has been encouraged by mass immunization campaigns and the resistance of political and religious leaders in Northern Nigeria to polio immunization after 2003 (Jegede 2007). There is a positive correlation between our shock and the relative duration of breastfeeding, and a negative and insignificant correlation with the relative likelihood of having a doctor assist delivery or a prenatal doctor's visit. The anomalous increase in breastfeeding despite decreases in other investments may be in part due to the increase in skilled work shown above, which might provide more flexibility for working mothers. It may also be driven in part by improved maternal health. Re-estimating 


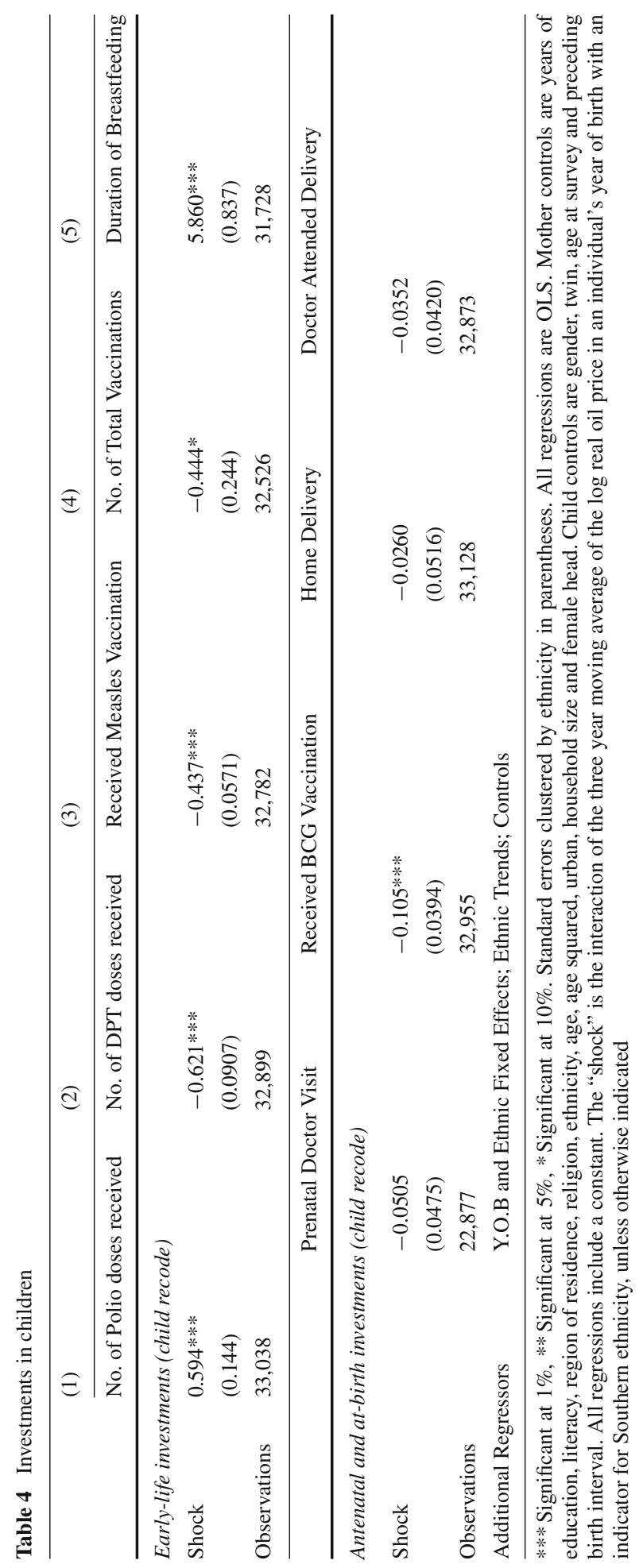


Table 5 Contemporary effects of oil prices

\begin{tabular}{llllll}
\hline & $(1)$ & $(2)$ & $(3)$ & $(4)$ & $(5)$ \\
& Partner works on farm & Earth floor & Has electricity & Weight & Working \\
\hline Shock & $-0.744^{* * *}$ & $-0.438^{* * *}$ & $0.451^{* * *}$ & 4.426 & $0.778^{* * * *}$ \\
& $(0.0984)$ & $(0.169)$ & $(0.156)$ & $(4.456)$ & $(0.102)$ \\
Observations & 36,177 & 49,712 & 49,510 & 42,422 & 50,218 \\
Ethnic F.E. & Yes & Yes & Yes & Yes & Yes \\
Year F.E. & Yes & Yes & Yes & Yes & Yes \\
Controls & Yes & Yes & Yes & Yes & Yes \\
Ethnic Trends & Yes & Yes & Yes & Yes & Yes \\
\hline
\end{tabular}

$* * *$ Significant at $1 \%, * *$ Significant at $5 \%, *$ Significant at $10 \%$. All regressions are OLS. Controls are dummy variables for urban residence, female household head, region of residence, religion and survey month. All regressions include a constant. The "shock" is the interaction of the three year moving average of the log real oil price in the survey year with an indicator for Southern ethnicity, unless otherwise indicated

these results separately for male and female children, we find similar patterns for girls and boys (not reported).

To look at how the relative circumstances of Southern women of child-bearing age respond to oil prices, we use the individual recode data from the DHS, similarly aggregated across the three waves for which ethnicity is available. Using the same approach as in our main results, we ask how household circumstances change contemporaneously with oil prices in the three years we have available. Results are reported in Table 5. We find that Southern households have relatively better living conditions, as measured by greater access to electricity and reduced probability of having an earth floor. We also find that women are more likely to work in the South in years of higher oil prices. Women's partners, by contrast, are relatively less likely to work on a farm in the south, either as a laborer or in self-employment. ${ }^{10}$ Together, these results suggest a mixed pattern. Although the relative living standards of southern households improve with higher oil prices, greater labor time outside the home reduces time with children and some investments in children. Less direct work in agriculture is consistent with the more general relative decline of southern agriculture suggested by the secondary literature.

\section{Conclusion}

In this paper, we have used a difference-in-difference approach to show that higher oil prices in an individual's year of birth predict more years of education, greater likelihood of having a skilled occupation, shorter heights, higher BMI, later marriage, lower fertility and higher likelihood of working for women that belong to Southern ethnic groups relative to Northern groups from the same birth cohort. The magnitudes of these effects are broadly in line with those found in similar early-life studies.

We interpret our results as consequences of the economic transformations that follow income gains for Southerners when oil prices are high. We find households in the South are relatively better off in periods of higher oil prices, but reduce some investments in their

${ }^{10}$ Using our baseline sample, we find no evidence that early-life oil prices affect a woman's partner's years of education or occupational skill, or the age gap of the respondent with her partner (not reported). 
children. This is consistent with an increase in women's working time and the movement of men out of agriculture. These mechanisms are also highlighted in the secondary literature (e.g. Bevan et al. 1999; Collier 1983) that has stressed a greater transition away from agriculture in Southern Nigeria during the oil boom than in the North. Both general equilibrium effects and government actions favored the relative expansion of manufacturing, public sector employment, and urbanization in the South.

Open Access This article is distributed under the terms of the Creative Commons Attribution 4.0 International License (http://creativecommons.org/licenses/by/4.0/), which permits unrestricted use, distribution, and reproduction in any medium, provided you give appropriate credit to the original author(s) and the source, provide a link to the Creative Commons license, and indicate if changes were made.

\section{References}

Abidoye, B., \& Calí, M. (2015). Income shocks and conflict: Evidence from Nigeria. World Bank Policy Research Working Paper 7213.

Acemoglu, D., Finkelstein, A., \& Notowidigdo, M. J. (2013). Income and health spending: Evidence from oil price shocks. Review of Economics and Statistics, 95(4), 1079-1095.

Adenikinju, A. F., \& Alaba, O. B. (1999). Energy use and productivity performance in the Nigerian manufacturing sector (1970-1990). Opec Review, 23(3), 251-264.

Adhvaryu, A., Fenske, J., \& Nyshadham, A. (2014a). Early life circumstance and adult mental health. University of Oxford, Department of Economics Working Papers 698.

Adhvaryu, A., Kala, N., \& Nyshadham, A. (2014b). Booms, busts, and household enterprise: Evidence from coffee farmers in Tanzania. Working Paper.

Adhvaryu, A., \& Nyshadham, A. (2016). Endowments at birth and parents' investments in children. Economic Journal, 126(593), 781-820.

Alesina, A. F., Michalopoulos, S., \& Papaioannou, E. (2016). Ethnic inequality. Journal of Political Economy, 124(2), 428-488.

Almond, D. (2006). Is the 1918 Influenza pandemic over? Long-term effects of in utero Influenza exposure in the post-1940 US population. Journal of Political Economy, 114(4), 672-712.

Almond, D., \& Currie, J. (2011). Killing me softly: The fetal origins hypothesis. The Journal of Economic Perspectives, 25(3), 153-172.

Almond, D., \& Mazumder, B. (2013). Fetal origins and parental responses. Annual Review of Economics, 5(1), $37-56$.

Angrist, J. D., \& Pischke, J.-S. (2008). Mostly harmless econometrics: An empiricist's companion. Princeton: Princeton University Press.

Archibong, B. (2016). Where local kings rule: Long-term impacts of precolonial institutions and geography on access to public infrastructure services in Nigeria. Working Paper.

Arezki, R., \& Brückner, M. (2011). Oil rents, corruption, and state stability: Evidence from panel data regressions. European Economic Review, 55(7), 955-963.

Arezki, R., \& Brückner, M. (2012). Commodity windfalls, polarization, and net foreign assets: Panel data evidence on the voracity effect. Journal of International Economics, 86(2), 318-326.

Baldwin, K., \& Huber, J. D. (2010). Economic versus cultural differences: Forms of ethnic diversity and public goods provision. American Political Science Review, 104(04), 644-662.

Bevan, D., Collier, P., \& Gunning, J. W. (1999). The political economy of poverty, equity, and growth: Nigeria and Indonesia. OUP Catalogue.

Bharadwaj, P., Løken, K., \& Neilson, C. (2013). Early life health interventions and academic achievement. American Economic Review, 103(5), 1862-1891.

Bienen, H. (1988). Nigeria: From windfall gains to welfare losses? Alan Gelb and Associates, Oil Windfalls: Blessing or Curse?, pages 227-261.

Blanden, J., Gregg, P., \& Macmillan, L. (2007). Accounting for intergenerational income persistence: Noncognitive skills, ability and education. The Economic Journal, 117(519), C43-C60.

Blau, D. M. (1999). The effect of income on child development. Review of Economics and Statistics, 81(2), 261-276.

Brückner, M., \& Ciccone, A. (2010). International commodity prices, growth and the outbreak of civil war in Sub-Saharan Africa. The Economic Journal, 120(544), 519-534. 
Burgess, R., Jedwab, R., Miguel, E., Morjaria, A., \& i Miquel, G. P. (2015). The value of democracy: Evidence from road building in Kenya. American Economic Review, 105(6), 1817-51.

Chua, A. (2004). World on fire: How exporting free market democracy breeds ethnic hatred and global instability. Random House LLC.

Chuku, C. A., Akpan, U. F., Sam, N. R., \& Effiong, E. L. (2011). Oil price shocks and the dynamics of current account balances in Nigeria. OPEC Energy Review, 35(2), 119-139.

Cogneau, D., \& Jedwab, R. (2012). Commodity price shocks and child outcomes: The 1990 Cocoa Crisis in Côte d'Ivoire. Economic Development and Cultural Change, 60(3), 507-534.

Collier, P. (1983). Oil and inequality in rural Nigeria. Agrarian policies and rural poverty in Africa. ed. by Dharam Ghai and Samir Radwan, pp. 191-217.

Collier, P. (1988). Oil shocks and food security in Nigeria. International Labour Review, 127, 761-782.

Cunha, F., Heckman, J. J., \& Schennach, S. M. (2010). Estimating the technology of cognitive and noncognitive skill formation. Econometrica, 78(3), 883-931.

Currie, J., \& Almond, D. (2011). Human capital development before age five. Handbook of Labor Economics, 4, 1315-1486.

Dahl, G. B., \& Lochner, L. (2012). The impact of family income on child achievement: Evidence from the earned income tax credit. The American Economic Review, 102(5), 1927-1956.

Deaton, A. (1999). Commodity prices and growth in Africa. The Journal of Economic Perspectives, 13(3), 23-40.

Dehejia, R., \& Lleras-Muney, A. (2004). Booms, busts, and babies' health. The Quarterly Journal of Economics, 119(3), 1091-1130.

Desmet, K., Ortuño-Ortín, I., \& Wacziarg, R. (2012). The political economy of linguistic cleavages. Journal of Development Economics, 97(2), 322-338.

Dev, P., Mberu, B. U., \& Pongou, R. (2016). Ethnic inequality: Theory and evidence from formal education in Nigeria. Economic Development and Cultural Change, 64(4), 603-660.

Duflo, E., Dupas, P., \& Kremer, M. (2015). Education, HIV, and early fertility: Experimental evidence from Kenya. The American Economic Review, 105(9), 2757-2797.

Easterly, W., \& Levine, R. (1997). Africa's growth tragedy: Policies and ethnic divisions. The Quarterly Journal of Economics, 112(4), 1203-1250.

Esteban, J., Mayoral, L., \& Ray, D. (2012). Ethnicity and conflict: An empirical study. The American Economic Review, 102(4), 1310-1342.

Fajana, S., et al. (2005). Industrial relations in the oil industry in Nigeria. ILO Sectoral Activities Programme, Working Paper, p. 237.

Falola, T., \& Heaton, M. M. (2008). A history of Nigeria. Cambridge: Cambridge University Press.

Franck, R., \& Rainer, I. (2012). Does the leader's ethnicity matter? Ethnic favoritism, education, and health in Sub-Saharan Africa. American Political Science Review, 106(02), 294-325.

Francois, P., Rainer, I., \& Trebbi, F. (2015). How is power shared in Africa? Econometrica, 83(02), 465-503.

Freund, B. (1978). Oil boom and crisis in contemporary Nigeria. Review of African Political Economy, 13, 91-100.

Galor, O. (2005). From stagnation to growth: Unified growth theory. Handbook of Economic Growth, 1, $171-293$.

Galor, O. (2011). Unified growth theory. Princeton: Princeton University Press.

Galor, O., \& Mountford, A. (2008). Trading population for productivity: Theory and evidence. The Review of Economic Studies, 75(4), 1143-1179.

Galor, O., \& Weil, D. (1996). The gender gap, fertility, and growth. American Economic Review, 86(3), 374-87.

Galor, O., \& Weil, D. N. (2000). Population, technology, and growth: From malthusian stagnation to the demographic transition and beyond. The American Economic Review, 90(4), 806-806.

Glennerster, R., Miguel, E., \& Rothenberg, A. D. (2013). Collective action in diverse Sierra Leone communities. The Economic Journal, 123(568), 285-316.

Griffin, J. M. (1985). OPEC behavior: A test of alternative hypotheses. The American Economic Review, 75(5), 954-963.

Hoyne, H., Schanzenbach, D. W., \& Almond, D. (2016). Long-run impacts of childhood access to the safety net. The American Economic Review, 106(4), 903-934.

Isen, A., \& Stevenson, B. (2010). Women's education and family behavior: Trends in marriage, divorce and fertility. National Bureau of Economic Research Working Paper No. w15725.

Jegede, A. S. (2007). What led to the Nigerian boycott of the polio vaccination campaign? PLoS Medicine, 4(3), e73.

Khan, S. A. (1994). Nigeria: The political economy of oil. Oxford: Oxford University Press.

Kruger, D. I. (2007). Coffee production effects on child labor and schooling in rural Brazil. Journal of Development Economics, 82(2), 448-463. 
Lukonga, I. (1994). Nigeria's non-oil exports: Determinants of supply and demand 1970-1990. International Monetary Fund WP/94/59.

Maccini, S., \& Yang, D. (2009). Under the weather: Health, schooling, and economic consequences of early-life rainfall. American Economic Review, 99(3), 1006-1026.

Marwah, H. (2014). What explains slow sub-Saharan African growth? Revisiting oil boom-era investment and productivity in Nigeria's national accounts, 1976-85. Economic History Review, 67(4), 993-1011.

Maurin, E. (2002). The impact of parental income on early schooling transitions: A re-examination using data over three generations. Journal of Public Economics, 85(3), 301-332.

Mehlum, H., Moene, K., \& Torvik, R. (2006). Institutions and the resource curse. The Economic Journal, 116(508), 1-20.

Michalopoulos, S., \& Papaioannou, E. (2013). Pre-colonial ethnic institutions and contemporary African development. Econometrica, 81(1), 113-152.

Michalopoulos, S., \& Papaioannou, E. (2016). The long-run effects of the scramble for Africa. The American Economic Review, 106(7), 1802-1848.

Miller, G., \& Urdinola, B. P. (2010). Cyclicality, mortality, and the value of time: The case of coffee price fluctuations and child survival in Colombia. The Journal of Political Economy, 118(1), 113.

Milligan, K., \& Stabile, M. (2011). Do child tax benefits affect the well-being of children? Evidence from Canadian child benefit expansions. American Economic Journal: Economic Policy, 3(3), 175-205.

Murdock, G. P. (1959). Africa: Its peoples and their culture history.

Murdock, G. P. (1967). Ethnographic atlas: A summary. Ethnology, 6(2), 109-236.

Mustapha, A. R. (2006). Ethnic structure, inequality and governance of the public sector in Nigeria (p. 24). Governance and Human Rights Programme Paper Number: United Nations Research Institute for Social Development Democracy.

Nigeria, U. N. D. P. (2006). Niger Delta human development report. Abuja: United Nations Development Programme.

NRGI (2013). The 2013 The Resource Governance Index. Natural Resource Governance Institute

Nunn, N. (2014). Gender and missionary influence in colonial Africa. In Akyeampong, E., Bates, R., Nunn, N., \& Robinson, J. (Eds.) African development in historical perspective.

Osili, U. O., \& Long, B. T. (2008). Does female schooling reduce fertility? Evidence from Nigeria. Journal of Development Economics, 87(1), 57-75.

Pinto, B. (1987). Nigeria during and after the oil boom: A policy comparison with Indonesia. The World Bank Economic Review, 1(3), 419-445.

Posner, D. N. (2004). Measuring ethnic fractionalization in Africa. American Journal of Political Science, 48(4), 849-863.

Roome, W. J. W. (1925). Ethnographie survey of Africa. Showing the tribes and languages; Also the Stations of Missionary Societies. E. Stanford Limited.

Ross, M. L. (2003). Nigeria's oil sector and the poor. In Position paper for DFID-Nigeria, UCLA, Los Angeles.

Ross, M. L. (2008). Oil, Islam, and women. American Political Science Review, 102(01), 107-123.

Sachs, J. D., \& Warner, A. M. (2001). The curse of natural resources. European Economic Review, 45(4), 827-838.

Sala-i-Martin, X., \& Subramanian, A. (2013). Addressing the natural resource curse: An illustration from Nigeria. Journal of African Economies, 22(4), 570-615.

Scherr, S. J. (1989). Agriculture in an export boom economy: A comparative analysis of policy and performance in Indonesia, Mexico and Nigeria. World Development, 17(4), 543-560.

Struthers, J. J. (1990). Nigerian oil and exchange rates: Indicators of 'Dutch disease'. Development and Change, 21(2), 309-341.

Tsui, K. K. (2011). More oil, less democracy: Evidence from worldwide crude oil discoveries. The Economic Journal, 121(551), 89-115.

Udosen, C., Etok, A.-I. S., \& George, I. (2010). Fifty years of oil exploration in Nigeria: The paradox of plenty. Global Journal of Social Sciences, 8(2), 37-47.

Vogl, T. S. (2015). Differential fertility, human capital, and development. The Review of Economic Studies, $83(1), 365-401$.

Walker, E. A. (2000). Structural change, the oil boom and the cocoa economy of southwestern Nigeria, 19731980s. The Journal of Modern African Studies, 38(01), 71-87.

Watts, M. J. (2013). Silent violence: Food, famine, and peasantry in northern Nigeria. University of Georgia Press.

Wlazlowski, S., Hagströmer, B., \& Giulietti, M. (2011). Causality in crude oil prices. Applied Economics, 43(24), 3337-3347.

World Bank. (2012). World development indicators 2012. World Bank Publications. 